\title{
AN EXPERIMENTAL STUDY ON THE PERFORMANCE OF MARINE CLAY SUBGRADE TREATED WITH SAWDUST AND LIME
}

\author{
Shaik Ishaq Ahmed \\ Post Graduate Student, \\ Dept. of Civil Engineering, \\ UCEK, JNTUK \\ Kakinada, A.P., India
}

\author{
Dr. K Purnanandam \\ Professor, \\ Dept. of Civil Engineering, \\ UCEK, JNTUK \\ Kakinada, A.P., India
}

\begin{abstract}
Roads are the arteries through which Indian economy grows. India is a country which is having a coastal line of $7516.6 \mathrm{~km}$. This coastal region mostly consists of marine clay deposits. For the construction of roads, using of locally available materials and soils will be economical. But in coastal region using marine clay (locally available) as a subgrade will not yield desirable results due to its poor engineering properties. Replacing soil is not economically feasible as it increases the budget of the project. Stabilization of the existing soil is a possible solution in such cases. Lime is a commonly available chemical and sawdust is a waste product from wood and timber industry. The study of using the above materials for the stabilization of marine clay is discussed here.
\end{abstract}

Keywords: Marine Clay, Sawdust, Lime, MDD, $O M C, C B R$.

\section{INTRODUCTION}

In the construction of pavements, subgrade plays a pivotal role. Subgrade performance will affect the lifespan of the pavement. An appropriate soil has to be selected which can be used as a subgrade. Poor performance of subgrade leads to high construction costs. To resolve this problem, different methods have been developed to minimize the variability in subgrade characteristics. Marine clay is one of the problematic soils which can be found on coastal region. Marine clays are microcrystalline in nature and it has clay minerals like illite, chlorite and kaolinite. Marine clays tend become stiff when dried but becomes soft when wet. High shrinkage and low shear strength are the properties of marine clay. Due to its poor properties, marine clay has to be pre-treated to be used as a subgrade in highways. In improving soft soil, generally replacement of soft soil with stronger material is to be used. Replacement of soil increases cost of the project. It was found that the utilization of the industrial wastes like sawdust is an alternative to stabilize the soil for various construction purposes. When an activator like lime is added to the sawdust, the results are very encouraging.

In the present study, sawdust and lime are added to marine clay to evaluate its performances through laboratory tests such as the standard proctor test and California bearing ratio test.

\section{REVIEW OF LITERATURE}

- Hydel et al (1993) presented the engineering properties of marine clay under cyclic loading.

- The influence of marine clay treated with air cooled slag with additives like calcium chlorite to improve the engineering properties was studied byPrasad Raju GVR et al.,(2001) .

- Chu, J et al(2002) reported that consolidation and permeability properties of Singapore marine clay based on laboratory and field investigations.

- GVR Prasad Raju et al., (2016) reported that Marine Clay when treated with various percentages of quarry dust as an admixture and Ferric chloride as an additive, the deformation and load carrying capacity of treated marine clay increased greatly.

\section{OBJECTIVES OF THE STUDY}

The objectives of the present experimental study are as follows:

- To determine properties of marine clay.

- To evaluate the performance of marine clay when stabilized with sawdust as an admixture. 


\section{International Journal of Engineering Applied Sciences and Technology, 2019 \\ Vol. 4, Issue 4, ISSN No. 2455-2143, Pages 383-389 \\ Published Online August 2019 in IJEAST (http://www.ijeast.com)}

- To determine suitability and performance of marine clay when stabilized with optimum of sawdust and lime when it is used as subgrade.

\section{MATERIALS USED}

\section{A. Marine clay}

Marine clay sample was collected from a dredging site, where dredging was carried out at a depth of $2.5 \mathrm{~m}$ below the sea level near Kakinada SeaPorts Ltd. The collected samples were black in color. The presence of sea shells indicated the presence of organic content. The hydrometer analysis conducted on marine clay shows $57.40 \%$ of clay and $25.40 \%$ of silt.

\begin{tabular}{|c|c|c|c|}
\hline $\mathrm{S}$. & \multicolumn{2}{|c|}{ Properties } & Untreated \\
\hline \multirow[t]{4}{*}{1} & \multirow[t]{4}{*}{$\begin{array}{c}\text { Soil } \\
\text { classification }\end{array}$} & $\begin{array}{c}\text { Gravel } \\
(\%)\end{array}$ & 0 \\
\hline & & Sand $(\%)$ & 17 \\
\hline & & Silt (\%) & 25.60 \\
\hline & & Clay (\%) & 57.40 \\
\hline 2 & \multicolumn{2}{|c|}{ Liquid limit (\%) } & 73.67 \\
\hline 3 & \multicolumn{2}{|c|}{ Plastic limit (\%) } & 26.40 \\
\hline 4 & \multicolumn{2}{|c|}{ Plasticity index (\%) } & 47.27 \\
\hline 5 & \multicolumn{2}{|c|}{ Shrinkage limit (\%) } & 11.87 \\
\hline 6 & \multicolumn{2}{|c|}{ Soil classification } & $\mathrm{CH}$ \\
\hline 7 & \multicolumn{2}{|c|}{ Specific gravity } & 2.342 \\
\hline 8 & \multicolumn{2}{|c|}{ Differential free swell (\%) } & 90 \\
\hline 9 & \multicolumn{2}{|c|}{$\operatorname{MDD}(\mathrm{g} / \mathrm{cc})$} & 1.324 \\
\hline 10 & \multicolumn{2}{|c|}{ OMC $(\%)$} & 34.48 \\
\hline 11 & \multicolumn{2}{|c|}{ CBR $(\%)$} & 1.137 \\
\hline 12 & \multicolumn{2}{|c|}{$\operatorname{cohesion}\left(\mathrm{kN} / \mathrm{m}^{\wedge} 2\right)$} & 90 \\
\hline 13 & \multicolumn{2}{|c|}{ Angle of internal friction } & $3.12^{0}$ \\
\hline
\end{tabular}

\section{B. Sawdust}

- Sawdust is a waste from the wood and timber industry. It is the residue generated by sawteeth when wood is cut into lumber.

- As it possesses a firing capacity, it is normally used as a fuel source in thermal processes (biomass). It is also used as insulating material.

- Sawdust is the residue generated by sawteeth when wood is cut into lumber.

\section{Lime}

Lime chemically known as Calcium oxide $(\mathrm{CaO})$, commonly known as quick lime is a widely used chemical.

\section{Physical Properties of Lime:}

- Lime is a white amorphous solid.

- It has a high melting point of $2600^{\circ}$

- It is highly stable and even fusion cannot decompose it.

Table 2: Physical Composition of Sawdust

\begin{tabular}{|c|c|c|}
\hline Property & $\begin{array}{c}\text { size (in } \\
\text { mm) }\end{array}$ & Value \\
\hline $\begin{array}{c}\text { Particle Size } \\
\text { Distribution }\end{array}$ & 4.75 & 100 \\
\cline { 2 - 3 } & 2.0 & 95 \\
\cline { 2 - 3 } & 0.6 & 81 \\
\cline { 2 - 3 } & 0.425 & 48 \\
\cline { 2 - 3 } & 0.21 & 30 \\
\hline & 0.075 & 9 \\
\cline { 2 - 3 } & & 2.05 \\
\hline \multirow{2}{*}{ Specific Gravity } & \\
\hline
\end{tabular}

Table 3 : Chemical Composition of Lime

\begin{tabular}{|c|c|c|}
\hline S.No & Components & Component \% \\
\hline 1 & Assay & 95 \\
\hline 2 & Chloride & 0.01 \\
\hline 3 & Sulphate & 0.2 \\
\hline 4 & Arsenic & 0.0004 \\
\hline 5 & Lead & 0.001 \\
\hline 6 & $\begin{array}{c}\text { Insoluble } \\
\text { Matter }\end{array}$ & \\
\hline
\end{tabular}

Courtesy: $w$ ww.sciencedirect.com 


\section{International Journal of Engineering Applied Sciences and Technology, 2019 \\ Vol. 4, Issue 4, ISSN No. 2455-2143, Pages 383-389 \\ Published Online August 2019 in IJEAST (http://www.ijeast.com)}

\section{LABORATORY STUDIES}

The laboratory studies were carried out on the samples of marine clay, marine clay treated with optimum of sawdust, marine clay treated with optimum of sawdust and lime.

\section{Atterberg limits:}

The liquid limit, plastic limit and thereby the plasticity index were determined using Casagrande's liquid limit apparatus as per the procedures laid down in IS: 2720 part 4 (1970) on marine clay; marine clay $+15 \%$ sawdust; Marine clay $+15 \%$ sawdust $+4 \%$ lime.

\section{Differential free swell index:}

This test is performed by pouring slowly $10 \mathrm{gm}$ of dry soil, $10 \mathrm{gm}$ of (soil+ lime), $10 \mathrm{gm}$ of (soil + lime + sawdust) passing through 425 micron sieve, in two different $100 \mathrm{cc}$ glass jars filled with distilled water and other with kerosene. The swollen volume of Marine Clay; Marine ClayLime; Marine clay-Lime -Sawdust mixes are recorded.

Differential

Free Swell

Index $\quad=$

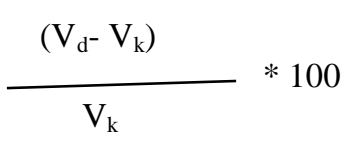

$\mathrm{V}_{\mathrm{d}}=$ Volume of soil in distilled water after 24 hours.

$\mathrm{V}_{\mathrm{k}}=$ volume of soil in kerosene after 24 hours.

\section{Specific Gravity Test:}

Specific gravity is the ratio of the mass of unit volume of soil at a stated temperature to the mass of the same volume of gas free distilled water at a stated temperature. The specific gravity of a soil is used in the phase relationship of air, water, and solids in a given volume of the soil. Specific gravity test was carried out by Pycnometer as per IS 2720 Part 3 (1980).

\section{Modified Proctor compaction Test:}

The optimum moisture content and maximum dry density have an important role in changing the strength properties of clay. Preparation of soil sample for proctor's compaction test was done as per IS: 2720 part-6 (1974).

\section{California Bearing Ratio Test:}

The California bearing ratio tests are conducted on Marine Clay, Marine Clay treated with sawdust, and Marine clay with optimum of sawdust and percentage variation of lime as per IS 2720 part 16 (1979), subjected to an Optimum moisture content obtained from Compaction test. The samples soaked for a curing period of 4 days. The test was conducted under a constant strain rate of $1.25 \mathrm{~mm} / \mathrm{min}$. The proving ring reading is noted for 50 divisions, and loading was continued until 3 or more readings were either decreasing or constant.

\section{RESULTS AND DISCUSSION}

Compaction and CBR values of marine clay treated with various percentages of lime

(a) Compaction Test Results :

Marine clay was replaced by sawdust in different percentages varying from $5 \%$ to $25 \%$ to improve its properties. Upon performing modified proctor compaction test, an optimum of $15 \%$ sawdust was obtained in this case. Thereafter Marine clay with $15 \%$ sawdust was treated with lime of percentage variations of $3 \%$ to $\% 7$. Finally an optimum of $4 \%$ lime was obtained. Tables 4,5 and figures 1, 2 and 3 present the OMC and MDD values of various mix proportions of marine clay.

Table 4: MDD Values for Various Mix Proportions of Marine Clay and Sawdust

\begin{tabular}{|c|c|c|c|}
\hline S.No & $\begin{array}{c}\text { MARINE } \\
\text { CLAY \% }\end{array}$ & $\begin{array}{c}\text { SAWDUST } \\
\%\end{array}$ & MDD g/cc \\
\hline 1 & 100 & 0 & 1.324 \\
\hline 2 & 95 & 5 & 1.262 \\
\hline 3 & 90 & 10 & 1.284 \\
\hline 4 & 85 & 15 & 1.361 \\
\hline 5 & 80 & 20 & 1.204 \\
\hline 6 & 75 & 25 & 1.193 \\
\hline
\end{tabular}

Table 5: MDD Values for Various Mix Proportions of Marine Clay, Sawdust and Lime

\begin{tabular}{|c|c|c|c|c|}
\hline S.No & $\begin{array}{c}\text { MARINE } \\
\text { CLAY \% }\end{array}$ & $\begin{array}{c}\text { SAWDUST } \\
\%\end{array}$ & LIME \% & $\begin{array}{c}\text { MDD } \\
\text { g/cc }\end{array}$ \\
\hline 1 & 82 & 15 & 3 & 1.304 \\
\hline 2 & 81 & 15 & 4 & 1.318 \\
\hline 3 & 80 & 15 & 5 & 1.296 \\
\hline 4 & 79 & 15 & 6 & 1.228 \\
\hline 5 & 78 & 15 & 7 & 1.168 \\
\hline
\end{tabular}

Table 6: CBR Values of Marine Clay Treated with various percentages of Sawdust 
International Journal of Engineering Applied Sciences and Technology, 2019

Vol. 4, Issue 4, ISSN No. 2455-2143, Pages 383-389

Published Online August 2019 in IJEAST (http://www.ijeast.com)

\begin{tabular}{|c|c|c|c|}
\hline S.No & $\begin{array}{c}\text { Marine } \\
\text { Clay \% }\end{array}$ & $\begin{array}{c}\text { Sawdust } \\
\%\end{array}$ & $\begin{array}{c}\text { Soaked } \\
\text { C.B.R }\end{array}$ \\
\hline 1 & 95 & 5 & 1.120 \\
\hline 2 & 90 & 10 & 2.017 \\
\hline 3 & 85 & 15 & 4.258 \\
\hline 4 & 80 & 20 & 0.896 \\
\hline 5 & 75 & 25 & 0.672 \\
\hline
\end{tabular}

\begin{tabular}{|c|c|c|c|c|c|}
\hline & $(\%)$ & & & & \\
\hline 8 & $\begin{array}{c}\text { CBR } \\
(\%)\end{array}$ & & 1.137 & 4.258 & 8.843 \\
\hline 9 & $\begin{array}{c}\text { Cohesio } \\
\mathrm{n}\left(\mathrm{kN} / \mathrm{m}^{\wedge}\right. \\
2)\end{array}$ & $\mathrm{C}$ & 90 & 74 & 55 \\
\hline 10 & $\begin{array}{c}\text { Angle of } \\
\text { internal } \\
\text { friction }\end{array}$ & $\Phi$ & $3.12^{0}$ & $6^{0}$ & $10^{0}$ \\
\hline
\end{tabular}

VII. GRAPHS

Table 7: CBR Values of Marine Clay Treated with

Various Percentages of Sawdust and Lime

\begin{tabular}{|c|c|c|c|c|}
\hline S.No & $\begin{array}{c}\text { MARINE } \\
\text { CLAY \% }\end{array}$ & $\begin{array}{c}\text { SAW } \\
\text { DUST } \\
\%\end{array}$ & $\begin{array}{c}\text { LIME } \\
\%\end{array}$ & $\begin{array}{c}\text { SOAKED } \\
\text { C.B.R }\end{array}$ \\
\hline 1 & 82 & 15 & 3 & 2.017 \\
\hline 2 & 81 & 15 & 4 & 8.843 \\
\hline 3 & 80 & 15 & 5 & 3.585 \\
\hline 4 & 79 & 15 & 6 & 2.465 \\
\hline 5 & 78 & 15 & 7 & 1.793 \\
\hline
\end{tabular}

Table 8: Laboratory Test Results Of The Untreated And Treated Marine Clay

\begin{tabular}{|c|c|c|c|c|c|}
\hline $\begin{array}{c}\text { S.N } \\
\mathrm{o}\end{array}$ & $\begin{array}{c}\text { Propertie } \\
\mathrm{s}\end{array}$ & $\begin{array}{c}\text { Sy } \\
\mathrm{mb} \\
\mathrm{ol}\end{array}$ & $\begin{array}{c}\text { Marin } \\
\text { e clay }\end{array}$ & $\begin{array}{c}\text { Mari } \\
\text { ne } \\
\text { clay } \\
+15 \% \\
\text { sawd } \\
\text { ust }\end{array}$ & $\begin{array}{c}\text { Marine } \\
\text { clay+1 } \\
5 \% \\
\text { sawdus } \\
\text { + } 4 \% \\
\text { lime }\end{array}$ \\
\hline 1 & $\begin{array}{c}\text { Liquid } \\
\text { limit (\%) }\end{array}$ & $\mathrm{W}_{\mathrm{l}}$ & 73.67 & 62.81 & 51.93 \\
\hline 2 & $\begin{array}{c}\text { Plastic } \\
\text { limit (\%) }\end{array}$ & $\mathrm{W}_{\mathrm{p}}$ & 26.40 & 28.34 & 30.09 \\
\hline 3 & $\begin{array}{c}\text { Plasticit } \\
\text { index } \\
(\%)\end{array}$ & $\mathrm{I}_{\mathrm{p}}$ & 47.27 & 34.47 & 21.84 \\
\hline 4 & $\begin{array}{c}\text { Specific } \\
\text { gravity }\end{array}$ & $\mathrm{G}$ & 2.342 & 2.563 & 2.603 \\
\hline 5 & $\begin{array}{c}\text { Different } \\
\text { ial free } \\
\text { swell } \\
\text { index } \\
(\%)\end{array}$ & $\mathrm{D}_{\mathrm{f}}$ & 90 & 35 & 24 \\
\hline 6 & $\begin{array}{c}\text { MDD(g/ } \\
\text { cc) }\end{array}$ & $\mathrm{Y}_{\mathrm{d}}$ & 1.324 & 1.361 & 1.318 \\
\hline 7 & OMC & $\mathrm{W}$ & 34.48 & 30.02 & 28.69 \\
\hline
\end{tabular}

COMPACTION GRAPHSAT A GLANCE

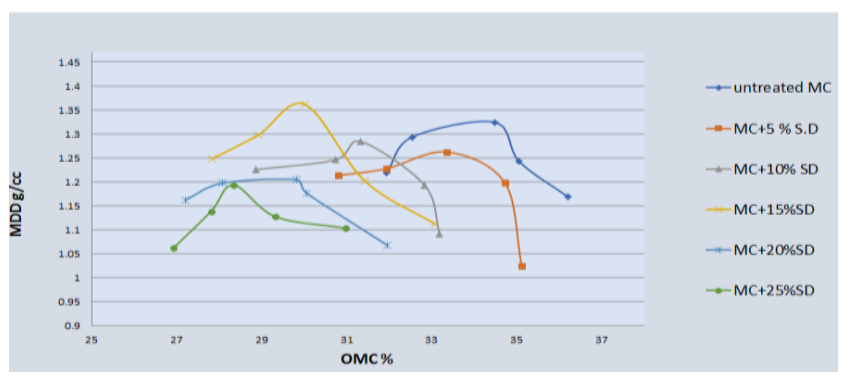

Fig.2 OMC and MDD values of treated marine clay treated with various percentages of sawdust 
International Journal of Engineering Applied Sciences and Technology, 2019

Vol. 4, Issue 4, ISSN No. 2455-2143, Pages 383-389

Published Online August 2019 in IJEAST (http://www.ijeast.com)

\section{COMPACTION GRAPHS AT A GLANCE}

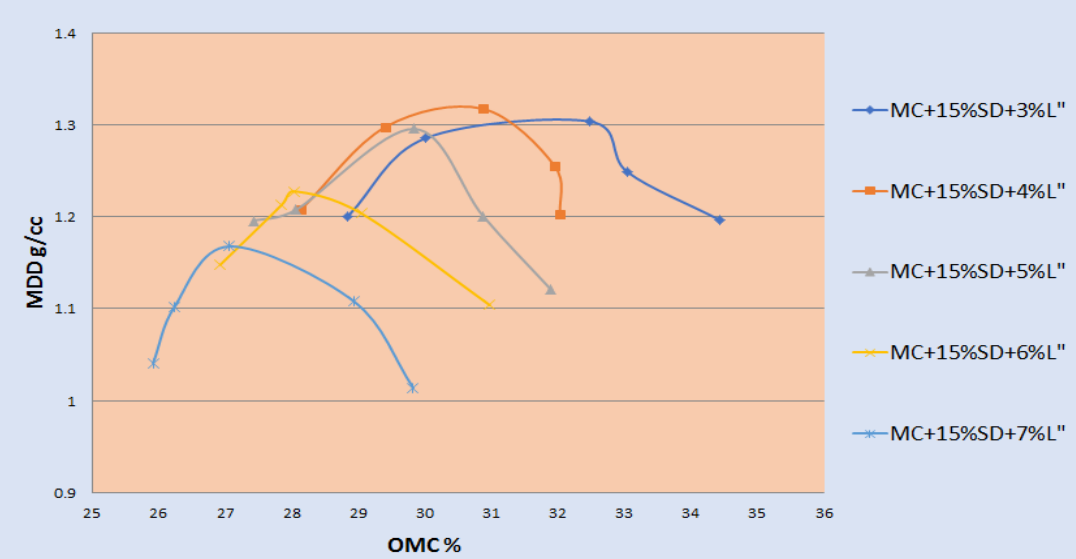

Fig.3 OMC and MDD plots of treated marine clay treated with various percentages of sawdust and lime

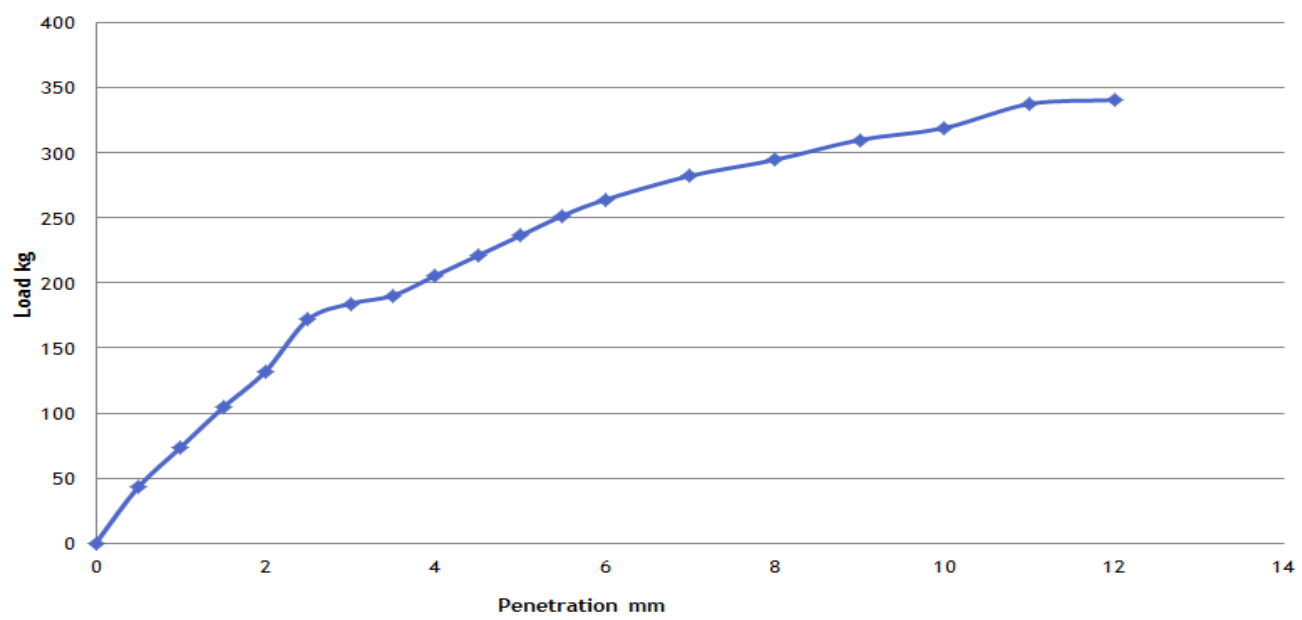

Fig.4 CBR graph of untreated marine clay

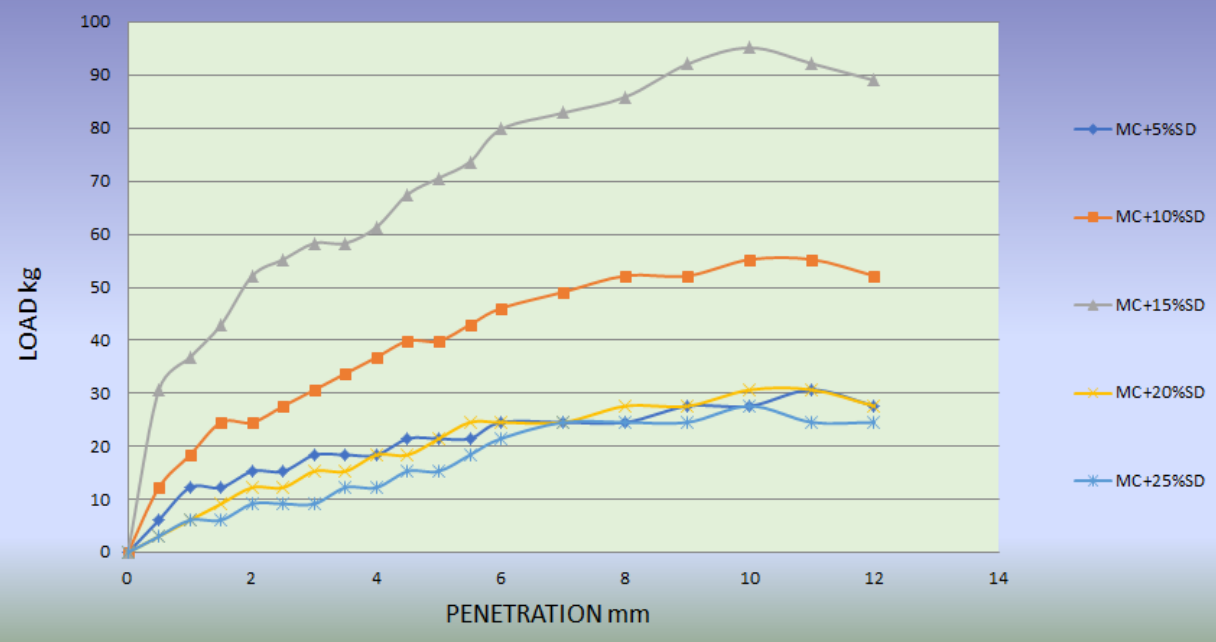

Fig.5 CBR graphs of treated marine clay with various percentages of sawdust 


\section{International Journal of Engineering Applied Sciences and Technology, 2019 \\ Vol. 4, Issue 4, ISSN No. 2455-2143, Pages 383-389 \\ Published Online August 2019 in IJEAST (http://www.ijeast.com)}

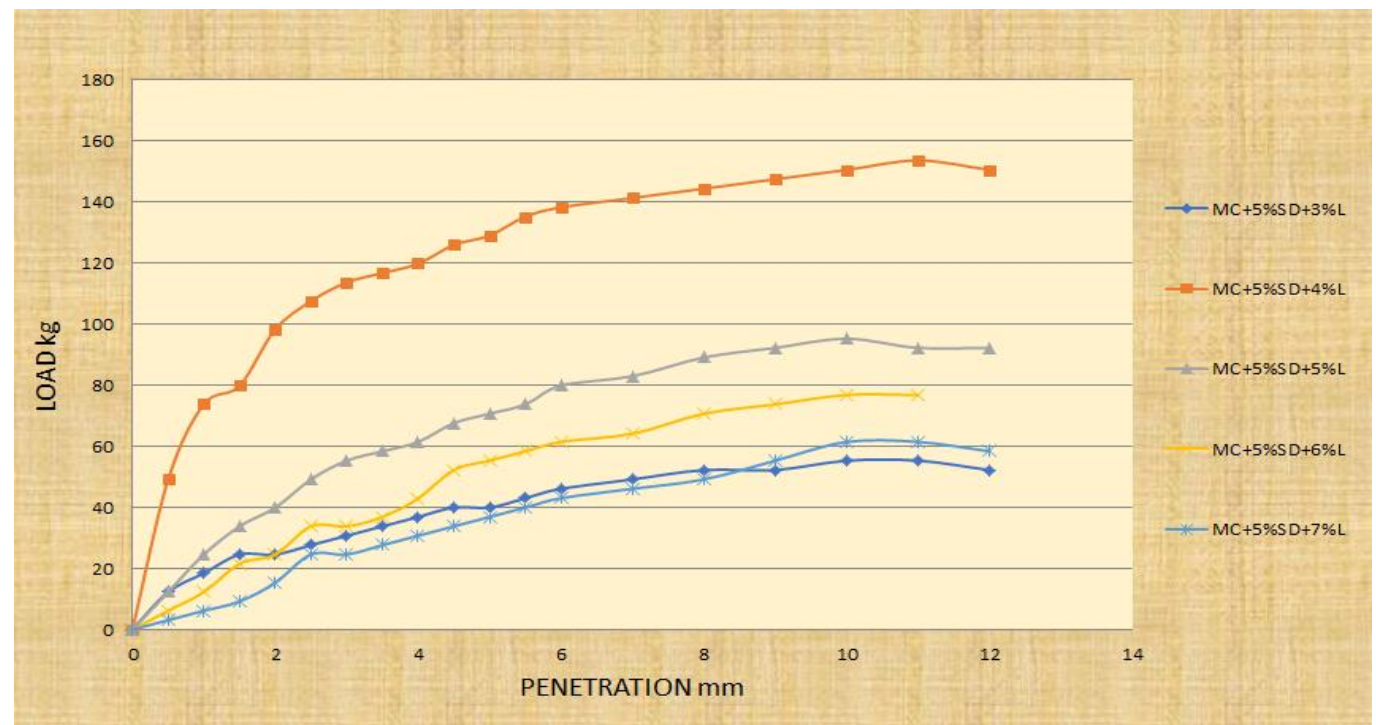

Fig.6 CBR graphs of treated marine clay with various percentages of sawdust and lime

\section{CONCLUSIONS}

Upon addition of $15 \%$ saw dust the following conclusions are made on the marine clay tested:

- The liquid limit has been decreased by $14.74 \%$.

- The plastic limit has been increased by $7.34 \%$.

- The plasticity index has been diminished by $27.50 \%$.

- The shrinkage limit was raised by $25.69 \%$.

- Specific gravity was increased by $8.81 \%$.

- DFS got lowered by $61.11 \%$.

- Maximum dry density was increased by $2.79 \%$.

- CBR value went up by $274.49 \%$.

On addition of $4 \%$ Lime and $15 \%$ saw dust to marine clay the following observations are made:

- The liquid limit has been decreased by $29.50 \%$.

- The plastic limit has been increased by $13.97 \%$.

- The plasticity index has been diminished by $53.79 \%$.

- The shrinkage limit was raised by $46.08 \%$.

- Specific gravity was increased by $20.54 \%$.

- DFS got lowered by $73.33 \%$.

- Maximum dry density was reduced by a margin of $0.45 \%$.

- CBR value went up by $589.79 \%$.

\section{ACKNOWLEDGEMENT}

I would like to express my deep sense of gratitude towards my guide Dr. K Purnanandam, Dept. of Civil Engineering, UCEK, JNTUK ,Kakinada for his huge support in my project and also in the publication of this paper. I also thank my other faculty members of Soil Mechanics and Foundation Engineering, lab technicians of Soil Mechanics Laboratory, Dept. of Civil Engineering, UCEK, JNTUK for extending their support by all means. I also wholeheartedly thank my classmates of SMFE, Dept. of Civil Engineering, UCEK, JNTUK for lending their help when needed.

\section{REFERENCES}

1. Teresa Sunny and Annie Joy (2016)," Study on the Effects of Marine Clay Stabilized with Banana Fibre", International Journal of Scientific Engineering and Research (IJSER), Volume- 4 Issue 3, pp.96-98 .

2. Prasada Raju GVR, P. Sowmya Ratna, DSV Prasad, (2016), "Performance of Recron-3s Fibre with Lime in Expansive Soil Stabilization", IOSR Journal of Mechanical and Civil Engineering (IOSR-JMCE), Volume 13, Issue 6, Pp. 74-79.

3. Prasad DSV, H Venkateswarlu, N Janardhan Rao, J Chaitanya Kumar (2015) "Strength Behaviour of Marine Clay Treated with Rice Husk Ash", International Journal of Engineering Sciences \& Research Technology, ISSN: 2277-9655, PP 561-567.

4. Dayakar Babu et al (2013) "Strength Behaviour of Marine Clay Stabilized with Lime - Quarry Rock Dust and Waste Plastics" Proceeding of Conference Paper June 2013. 
5. Koteswara Rao.D, G.V.V. Rameswara Rao, P.R.T. Pranav (2012) "A Laboratory Study on the Effect of Rice Husk Ash \& Lime on the Properties of Marine Clay" International Journal of Engineering and Innovative Technology (IJEIT), Volume 2, Issue 1, PP 345-353.

6. Rajasekaran, G and Narasimha Rao, S (2002), Compressibility Behaviour of Lime Treated Marine Clay, Journal of Ocean Engineering, volume-29, pp. 545-559.

7. IS : 2720 Part - 3 (1980) : Determination of Specific Gravity .

8. IS : 2720 Part - 4 (1975) : Grain size analysis.

9. IS : 2720 Part - 5 (1970) : Determination of Liquid Limit and Plastic Limit

10. IS : 2720 Part - 6 (1972) : Determination of Shrinkage Limit .

11. IS : 2720 Part - 6 ( 1974) : Determination of Dry Density and Optimum Moisture Content .

12. IS : 2720 Part -16 ( 1979) : Determination of California Bearing Ratio . 